\title{
Determination of Hydrogen Peroxide on Modified Glassy Carbon Electrode by Polytetrakis(2-aminophenyl)porphyrin Nanowire
}

\author{
Haesang Jeong," Songmi Kim, Heejin Seol, Jung-Min You, Eun Seon Jeong, Seul Ki Kim, \\ Kyung-Sik Seo, and Seungwon Jeon ${ }^{\times}$
Department of Chemistry and Institute of Basic Science, Chonnam National Eniversity, Gwangiu 500-757, Korea
${ }^{\dagger}$ Wano Bio Application Lab., Momed Co., Grangju 500-480. Korea. ${ }^{*}$ E-mail: swjeoniáchonam ac.kr \\ Received Hay 7, 2009, Accepted October 15, 2009
}

\begin{abstract}
Nanowires of polytetrakis $(0$-aminophenyl)porphyrin (PTAPPNW) were fabricated by electrochemical polymerization with the cyclic voltammetric method in anodic aluminum oxide (AAO) membranes. The glassy carbon electrode (GCE) nodified by PTAPPNW, single-walled carbon nanotubes (SWNT) and Nafion as a binder was investigated with voltanmetric methods in a phosphate buffer saline (PBS) solution at $\mathrm{pH}$ 7.4. The PTAPPNW + SWNT + Nafion/GCE exhibited strongly enhanced voltammetric and amperometric sensitivity towards hydrogen peroxide $\left(\mathrm{H}_{2} \mathrm{O}_{2}\right)$, which shortened the response time and enhanced the sensitivity for $\mathrm{H}_{2} \mathrm{O}_{2}$ detemination at an applied potential of $0.0 \mathrm{~V}$ by amperometric method. The PTAPPNW + SWNT + Nafion/GCE can be used to monitor $\mathrm{H}_{2} \mathrm{O}_{2}$ at very low concentrations in biological $\mathrm{pH}$ as an efficient electrochemical $\mathrm{H}_{2} \mathrm{O}_{2}$ sensor.
\end{abstract}

Key Words: Porphyrin nanowire. Single-walled carbon nanotubes, Hydrogen peroxide, Electrochemical sensor. Amperometry

\section{Introduction}

Hydrogen peroxide $\left(\mathrm{H}_{2} \mathrm{O}_{2}\right)$ is a pale-blue. covalent liquid that is freely miscible with water and apparently able to cross cell membranes readily. via unknown pathways. ${ }^{1}$ Numerous papers have described high (usually $\geq 50 \mu \mathrm{M}$ ) levels of $\mathrm{H}_{2} \mathrm{O}_{2}$ as being cytotoxic to a wide range of animal. plant and bacterial cells in culture. ${ }^{1 \cdot 5}$ It is therefore widely thought that $\mathrm{H}_{2} \mathrm{O}_{2}$ is very toxic in wo and must be rapidly eliminated. employing enzymes such as catalases. peroxidases (especially glutathione peroxidases) and thioredoxin-linked systems. ${ }^{1,6-9} \mathrm{H}_{2} \mathrm{O}_{2}$ is an increasingly recognized. small molecule mediator of physiology. aging, and disease in living organisms. ${ }^{15.15}$ In this regard. aberrant production or accumulation of $\mathrm{H}_{2} \mathrm{O}_{2}$ within cellular mitochondria over time due to envirormental stress and/or genetic mutation is connected to serious diseases where age is a risk factor. including cancer and neurodegenerative Alzheimer's. Parkinson's. and Huntington's diseases. ${ }^{16.18}$

Recently, many' researchers have used the measurement of $\mathrm{H}_{2} \mathrm{O}_{2}$ concentration for the analysis of glucose in living systems. Titanium-porphyrins and cobalt-porphyrins as $\mathrm{H}_{2} \mathrm{O}_{2}$ cataly sts have been used for the determination of glucose and $\mathrm{H}_{2} \mathrm{O}_{2}$ levels. ${ }^{15-1}$ After the discovery of carbon nanotubes (CNTs). they were used for the determination of dopamine ${ }^{2-30}$ serotonin. ${ }^{29.30}$ norepinephrine, ${ }^{31}$ dilydronicotinamide adenine dinucleotide $(\mathrm{NADH}),{ }^{3-3+3}$ and ascorbic acid (AA) ${ }^{35}$ because CNTs have excellent biocompatibility and electron transfer ability. Meanwhile. many papers have used CNTs modified with molecular derivatives or enzymes to measure glucose and $\mathrm{H}_{2} \mathrm{O}_{2}{ }^{36-41}$ The gold electrode modified with SOD and polypy rrole was used to determine the $\mathrm{H}_{2} \mathrm{O}_{2}$ generated from the decomposition of active oxygen. ${ }^{\text {t? }}$

Their modified electrodes. with supporting molecules as a binder or ion-exchanger. have been applied to the determination of many biomolecules. Since the pioneering work of Martin's group. nanomaterials of polyaniline, polypy rrole and polythiophene have been prepared using tenplate synthesis. ${ }^{42-65}$ Several types of nanowires or nanotubes have been prepared using multiporous anodic aluninum oxide (AAO) membrane. in order to increase their tensile strength and size unifonnity. ${ }^{4: 54}$ Voltammetry is very useful for the preparation of high quality nanowires in the multiporous AAO substrate. due to the control of electrochemical values. ${ }^{5-59}$

In this study. the nanowires of polytetrakis(o-aminophenyl) porphyrin (PTAPPNW) were prepared by electrochemical polymerization with cyclic voltammetric method in AAO membranes. We studied the electrochenical properties of PTAPPNW and its application to the determination of $\mathrm{H}_{2} \mathrm{O}_{2}$ by electrocatalytic reduction. The modified GCE prepared with single-walled CNTs (SWNT). Nafion and polyporphyrin nanowire was investigated for its $\mathrm{H}_{2} \mathrm{O}_{2}$ voltanmetric and amperometric response.

\section{Experimental Section}

Chemicals and electrochemical appjaratus. Tetrakis $(0$-aminophenyl) porphyrin (TAPP) was purchased from Midcentury SWNT (1.2 $1.5 \mathrm{~nm}$ in diameter produced by are method) were purchased from Aldrich. AAO films ( $\mathrm{d}=200 \mathrm{~nm}$. anodisc) for use as a template for the nanowires were purchased from Whatman. $\mathrm{H}_{2} \mathrm{O}_{2}$. and all other reagents used were of analytical grade. The $\mathrm{pH}$ of phosphate buffer saline (PBS) solution was adjusted with $0.1 \mathrm{M} \mathrm{H}_{3} \mathrm{PO}_{4}$ and $0.1 \mathrm{M} \mathrm{NaOH}$. High purity argon was used for deaeration. All experiments were carried out at room temperature. Doubly distilled water with resistibility over $18 \mathrm{M} \Omega \mathrm{cm}^{-1}$ in a quartz apparatus was used to prepare all aqueous electrolyte solutions. 


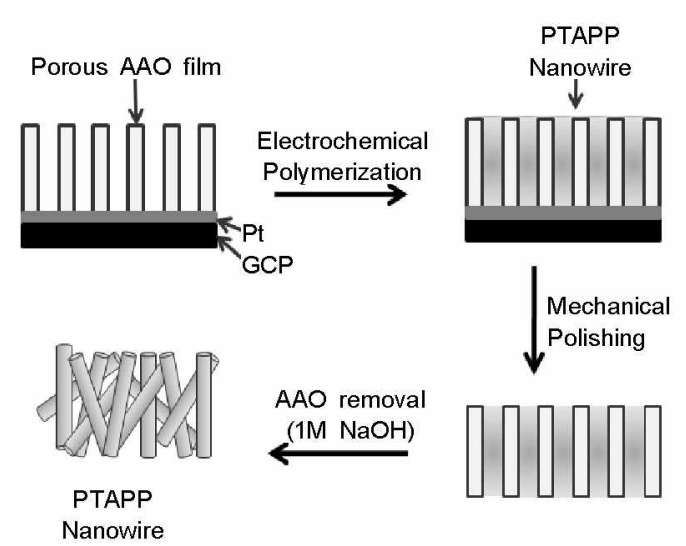

Figure 1. Schematic of PTAPP nanowire fabrication by electrochemical polymerization.

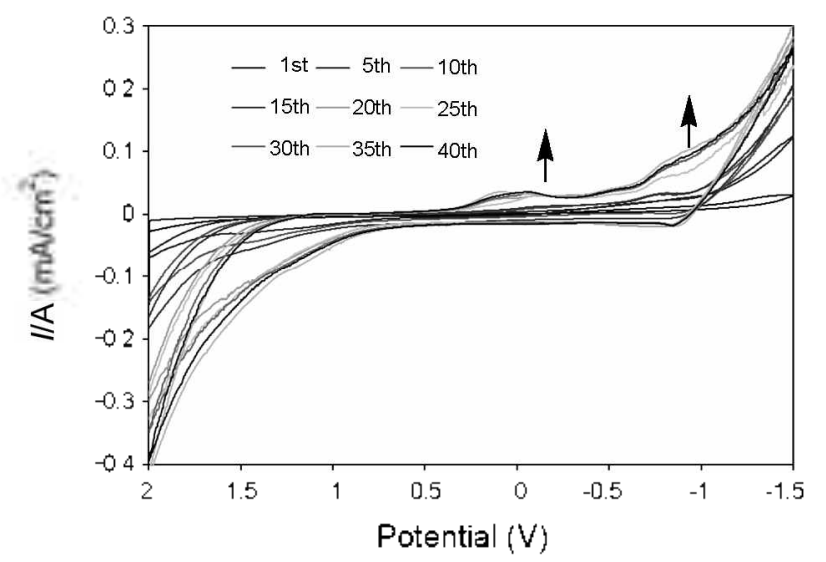

Figure 2. CVs of electrochemical polymerization of TAPP in PBS at the AAO membrane. Scan rate: $0.02 \mathrm{~V} / \mathrm{s}, 40$ cycles.

The voltammetric measurements were accomplished with a three-electrode potentiostat [Bioanaly tical Systems (BAS) 100 $\mathrm{B} / \mathrm{W}$ and $\mathrm{CH} 700 \mathrm{Cl}$ in a ground Faraday cage. A platinum-wire electrode was used as an auxiliary electrode. $\mathrm{A} \mathrm{Ag} / \mathrm{AgCl}$ electrode $(3.0 \mathrm{M} \mathrm{NaCl})$ supplied by BAS was used as the reference electrode. A $3.0 \mathrm{~mm}$-diameter GCE and glassy carbon plate (GCP: $25 \times 25 \mathrm{~mm}$ ) were used as a working electrode. the surface of which was highly polished with alumina paste prior to each experiment. All reported potentials were measured with respect to a $\mathrm{Ag} / \mathrm{AgCl}$ electrode at room temperature under argon atmosphere. The $\mathrm{pH}$ measurements were performed by a $\mathrm{pH}$ glass electrode with a JENCO meter. A field emission scanning electron microscope (FE-SEM) image of the modified electrode was obtained on a JSM-7500F FE-SEM microanalyzer (JEOL).

Preparation of PTAPPNW. The TAPP ( $1 \mathrm{mg}$ ) solution of $\mathrm{CH}_{3} \mathrm{CN}: \mathrm{CH}_{3} \mathrm{Cl}(\mathrm{l}: 1,1 \mathrm{~mL})$ sank into the pores of the Ptcoated (ab. $30 \mathrm{~nm}$ ) AAO membrane slowly after which PTAPPNW was prepared under cyclic voltammetry conditions by sweeping the potential from 2.0 to $-1.5 \mathrm{~V}$ versus $\mathrm{Ag} / \mathrm{AgCl}$ with a scan rate of $0.02 \mathrm{~V} / \mathrm{s}$. for 40 cycles at room temperature in PBS solution ${ }^{61}$ After the preparation of PTAPPNW, the AAO membrane was treated with $1.0 \mathrm{M} \mathrm{NaOH}$ solution to dissolve the AAO template. and then washed several times with distilled water carefully and filtered with polycarbonate membrane (pore size: $5 \mu \mathrm{m}$ ). The PTAPPNW was obtained and dispersed in water. Fig. I illustrates the scheme of the PTAPPNW fabrication by electrochemical poly merization.

Modification of the electrode. The SWNTs were treated by sonication in a mixture of $\mathrm{HNO}_{3}$ and $\mathrm{H}_{2} \mathrm{SO}_{4}$ for $4 \mathrm{~h}$ at $60^{\circ} \mathrm{C}$, and then washed several times with distilled water carefully' and filtered with a polycarbonate membrane (pore size: $5 \mu \mathrm{m}$ ). Meanwhile. the GCE surface was highly polished with alumina paste. sonicated with ultrasonic agitation for $5 \mathrm{~min}$ washed with $1.0 \mathrm{M} \mathrm{HCl}$ solution and then rinsed with distilled water several times and methanol finally. After being cleaned thoroughly. the GCE was coated with the $0.5 \%$ Nafion solution containing PTAPPNW (l mg/mL) and SWNT ( $1 \mathrm{mg} / \mathrm{mL})$, and then the solvents were evaporated in air at room temperature. The PTAPPNW + SWNT + Nafion/GCE have been used as the working electrode for the determination of $\mathrm{H}_{2} \mathrm{O}_{2}$. Meanwhile. $0.5 \%$ Nafion solutions of PTAPPNW ( $\mathrm{mg} / \mathrm{nL})$ and of SWNT ( $\mathrm{lmg} / \mathrm{mL}$ ) were used for the modified electrodes of PTAPPNW + Nafion/GCE and SWNT + Nafion/GCE, respectively. Before and after each experiment. the PTAPPNW + SWNT + Nafion/ GCE have been washed with distilled water. All experiments were carried out in a $15 \mathrm{~mL}$ electrolytic cell with $5 \mathrm{~mL}$ PBS solutions. while the dioxygen was contimuously removed by purging with high-purity argon.

\section{Results and Discussion}

Electnochemical propenties of PTAPPNW. The synthesizing process of PTAPPNWs is sintele and easy to control. Before the electropolymerization starts. it is always essential that the AAO tentate be inumersed into nonomer solution for adequate time to ensure monomer diffusion in the narrow pores of the template. After 40 cycles of electropolymerization the deposition was completed. Fig. 2 represents the cyclic voltammograms (CVs) recorded during the electropolymerization of TAPP at AAO membrane by sweeping the potential from 2.0 to $-1.5 \mathrm{~V}$ versus $\mathrm{Ag} / \mathrm{AgCl}$ with a scan rate of $0.02 \mathrm{~V} / \mathrm{s}$ for 40 cycles at room temperature in PBS solutions. The cathodic scan gave two peaks at about $0.0 \mathrm{~V}$ and $-0.8 \mathrm{~V}$. The two peaks were unclear at initial scan. but became clear after the 20th cycle. Until the 20th cycle. the reduction currents increased markedly, but after the 20th cycle they grew slightly. In this study, an applied potential of around $0.0 \mathrm{~V}$ was used for the determination of $\mathrm{H}_{2} \mathrm{O}_{2}$ by electrochemical reduction.

The AAO template was treated in a $1.0 \mathrm{M} \mathrm{NaOH}$ solution for 1 hour to obtain the PTAPPNW nanowire by removal of the AAO membrane. The PTAPPNWs were characterized using FE-SEM. Fig. 3 exhibits the FE-SEM image of the synthesized PTAPPNW. Figs. 3A and B show the very uniform shape of the PTAPPNW The average length of the PTAPPNW was $40 \mu \mathrm{m}$ and the diameter was about $200 \mathrm{~nm}$. which corresponded to the diameter of the nanopores in the blank AAO membrane. Fig. $3 \mathrm{C}$ exhibits the binding shape of SWNT on the PTAPPNW. The prepared nanowires were straight. contimuous. and smooth, indicating that the PTAPPNW can be prepared in a very uniform and controlled way.

Electrochemical response of $\mathrm{H}_{2} \mathrm{O}_{2}$ at the modified GCE. The CVs of $5.0 \mathrm{mMH}_{2} \mathrm{O}_{2}$ at the bare GCE. PTAPPNW + Nafion 


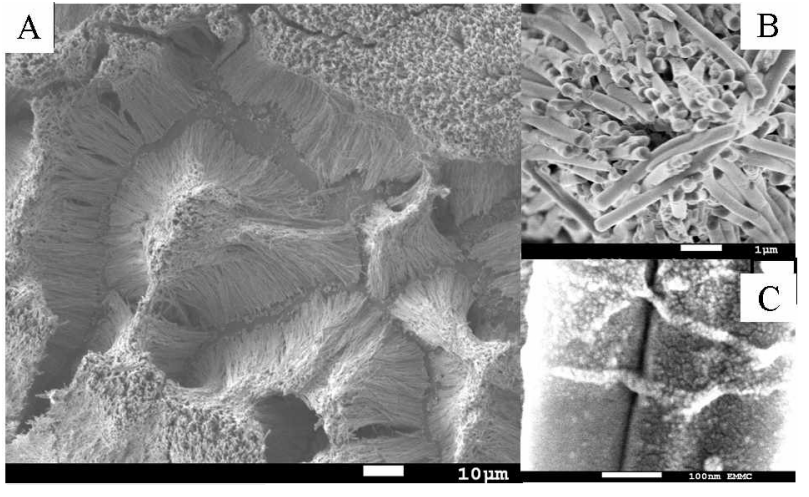

Figure. 3. FE-SEM images of PTAPPNW $(\mathrm{A} ; \times 500),(\mathrm{B} ; \times 8,500)$ and PTAPPNW + SWNT $(\mathrm{C} ; \times 150,000)$.

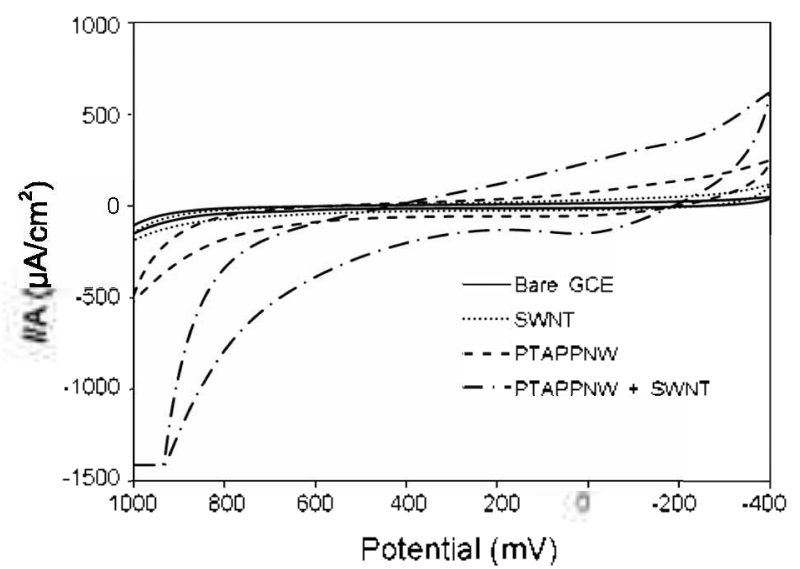

Figure 4. CVs obtained at the bare GCE, SWNT + Nation/GCE, PTAPPNW + Nafion/GCE and PTAPPNW + SWNT + Nafion/GCE at $\mathrm{pH} 7.4$ in a $\mathrm{PBS}$ solution containing $5.0 \mathrm{~m} \mathrm{M} \mathrm{H}_{2} \mathrm{O}_{2}$. Scan rates: 0.1 $\mathrm{V} / \mathrm{s}$

GCE. SWNT + Nafion/GCE. and PTAPPNW + SWNT + Nafion/ GCE in the PBS solution at $\mathrm{pH} 7.4$ are shown in Fig. 4 . The reduction peak current of $\mathrm{H}_{2} \mathrm{O}_{2}$ at bare GCE was very small. but was slightly increased at SWNT and PTAPPNW. Based on the PPNW + SWNT curve of Fig. 4, the reduction peak current of $\mathrm{H}_{2} \mathrm{O}_{2}$ was increased markedly. with a broad shape around $0.0 \mathrm{~V}$. The response of $\mathrm{H}_{2} \mathrm{O}_{2}$ at PTAPPNW + SWNT + Nafion/GCE gave a remarkable increase when compared with the other electrodes used in this work.

Fig. 5 illustrates the amperometric response of the SWNT + Nafion/GCE. PTAPPNW + Nafion/GCE, and PTAPPNW + SWNT + Nafion/GCE with $5 \mu \mathrm{L}$ casting solution to subsequent additions of $1.0 \mathrm{mM} \mathrm{H}_{2} \mathrm{O}_{2}$ in PBS at an applied potential of 0.0 V. In Fig. 5. the amperometric response of $\mathrm{H}_{2} \mathrm{O}_{2}$ at the PTAP. $\mathrm{PNW}+\mathrm{SWNT}+\mathrm{Nafion} / \mathrm{GCE}$ was remarkably increased compared with the other electrodes studied. The PTAPPNW + SWNT + Nafion/GCE enhanced the amperometric response of $\mathrm{H}_{2} \mathrm{O}_{2}$ more than 5 or 10 times greater than those at the other modified electrodes. The PTAPPNW + SWNT + Nafion/GCE responded rapidly to the changing $\mathrm{H}_{2} \mathrm{O}_{2}$ concentration. with a response time of within $5 \mathrm{~s}$. The inset of Fig. 5 shows the plot of the response currents ws. the $\mathrm{H}_{2} \mathrm{O}_{2}$ concentration.

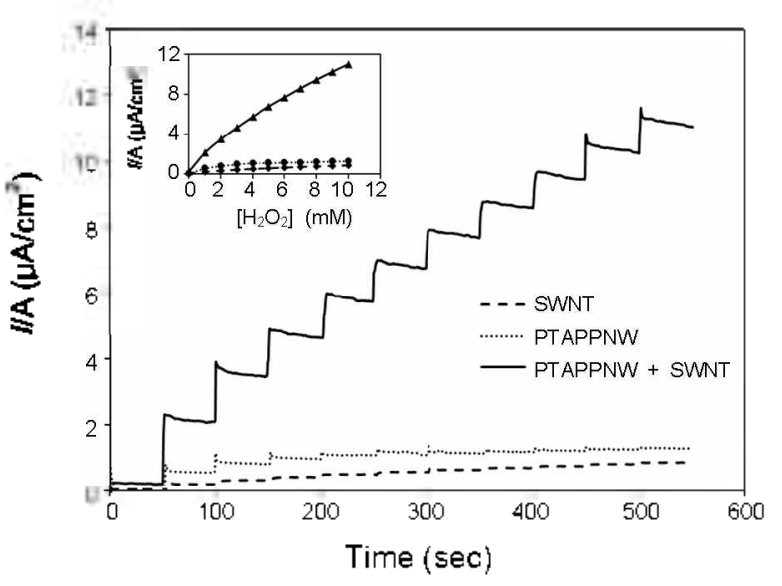

Figure 5. Amperometric response of $0.0-10.0 \mathrm{mM} \mathrm{H}_{2} \mathrm{O}_{2}(1.0 \mathrm{mM}$ step j at SWNT + Nation/GCE. PTAPPNW + Nation/GCE and PTAPPNW + SWNT + Nafion/GCE with 5.0 uL casting solution at an applied potential of $0.0 \mathrm{~V}$ in $0.1 \mathrm{M}$ PBS pH 7.4. Inset: plot of the response currents is. the $\mathrm{H}_{2} \mathrm{O}_{2}$ concentration.

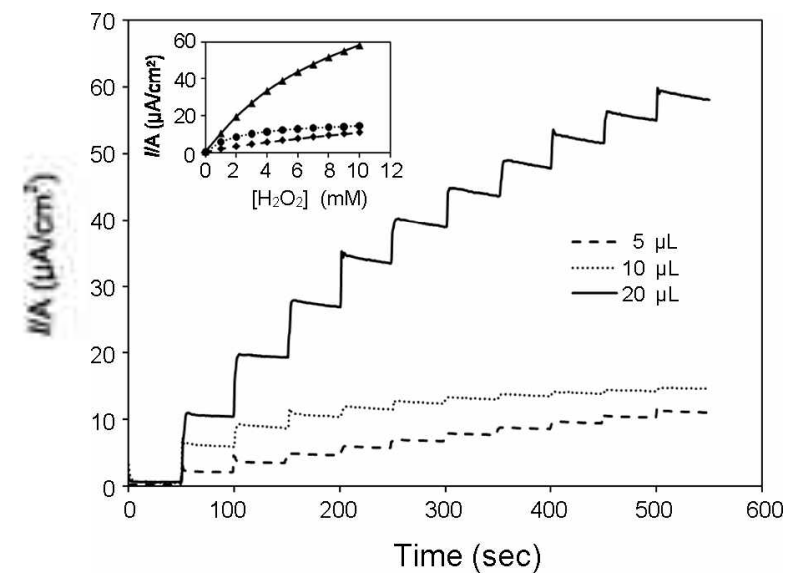

Figure 6. Amperometric response of $0.0 \sim 10.0 \mathrm{mM} \mathrm{H}_{2} \mathrm{O}_{2}(1.0 \mathrm{mM}$ step $)$ at 5,10 and $20 \mu \mathrm{L}$ casting mixture solutions and PTAPPNW + SWNT + Nafion/GCE at an applied potential of $0.0 \mathrm{~V}$ in $0.1 \mathrm{M}$ PBS $\mathrm{pH}$ 7.4. Inset: plot of the response cunents $\mathrm{r}$ 's the $\mathrm{H}_{2} \mathrm{O}_{2}$ concentration.

The composite of the SWNT and PTAPPNW in the electrode film (see Fig. 3C) should promote the sensitivity of $\mathrm{H}_{2} \mathrm{O}_{2}$ detection, because PTAPPNW as well as SWNT have high surface area and excellent electrical property. and Nafion is a negatively charged polymer and surfactant.

Fig. 6 illustrates the amperometric response of $\mathrm{H}_{2} \mathrm{O}_{2}$ at the PTAPPNW + SWNT + Nafion/GCE with 5. 10. and $20 \mu \mathrm{L}$ casting solution to subsequent additions of $1.0 \mathrm{mM} \mathrm{H}_{2} \mathrm{O}_{2}$ in $\mathrm{PBS}$ at an applied potential of $0.0 \mathrm{~V}$. In Fig. 6 . the amperometric response of $\mathrm{H}_{2} \mathrm{O}_{2}$ at the PTAPPNW + SWNT + Nafion/GCE with $20 \mu \mathrm{L}$ casting solution was remarkably increased. and was enlanced $4 \sim 6$ times more than those at the other modified electrodes. This crucial enhancement may be attributed to the increase of the surface area of the modified electrodes due to the increase of the amount of catalysts as nanostructures. The inset of Fig. 6 provides a plot of the response currents $v$. the $\mathrm{H}_{2} \mathrm{O}_{2}$ concentration. It was difficult to get a stable electrode in the modified GCE with a casting solution over $20 \mu \mathrm{L}$, and the 


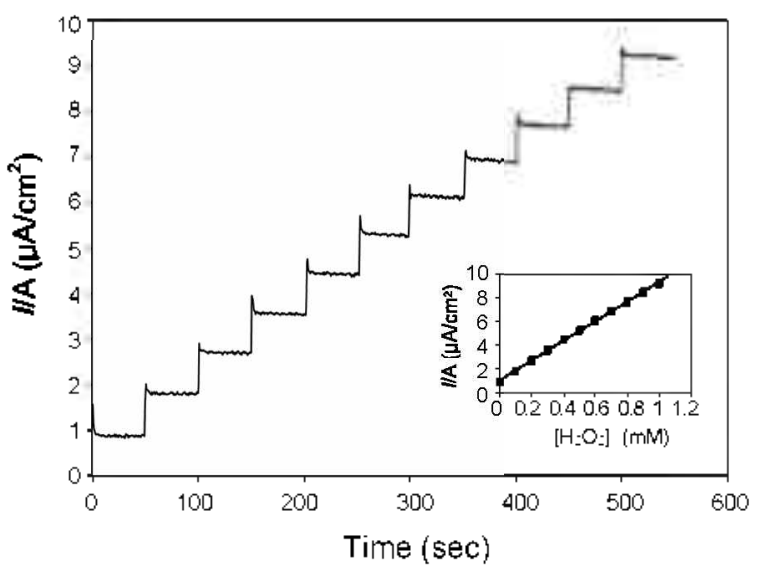

Figure 7. Amperometric response of $0.0-1.0 \mathrm{mM} \mathrm{H}_{2} \mathrm{O}_{2}(0.1 \mathrm{mM}$ step) at $20 \mu \mathrm{L}$ casting mixture solution and PTAPPNW + SWNT + Nafion/GCE at an applied potential of 0.0 V in 0.1 M PBS pH 7.4. Inset: plot of the response currents vs. the $\mathrm{H}_{2} \mathrm{O}_{2}$ concentration.

response current was saturated.

Fig. 7 illustrates the amperometric response of $\mathrm{H}_{2} \mathrm{O}_{2}$ at the PTAPPNW + SWNT + Nafion/GCE with $20 \mu \mathrm{L}$ casting solution to subsequent additions of $0.1 \mathrm{mM} \mathrm{H}_{2} \mathrm{O}_{2}$ in $\mathrm{PBS}$ at an applied potential of $0.0 \mathrm{~V}$. The inset of Fig. 7 gives the plot of the response currents $v$. the $\mathrm{H}_{2} \mathrm{O}_{2}$ concentration. In the low concentration region between $100 \mu \mathrm{M}$ and $1.0 \mathrm{mM}$ the linear regression equation was obtained as $I_{p} / \mu \mathrm{A}=0.589[\mathrm{C}] / \mu \mathrm{M}+0.072$, with a correlation coefficient of 0.999 . The sensitivity is $8.41 \mu \mathrm{A}$ $\mu \mathrm{M}^{1} \mathrm{~cm}^{-2}$ which is higher value rather than $0.318 \mu \mathrm{A} \mu \mathrm{M}^{1} \mathrm{~cm}^{-2}$ obtained from the literature. ${ }^{21}$ The detection limit (DL) was $1.0 \mu \mathrm{M}$ at a signal-to-noise ratio $(\mathrm{S} / \mathrm{N})$ of 3 in the $\mathrm{PBS}$ solution at $\mathrm{pH} 7.4$, representing a physiological $\mathrm{pH}$. This $\mathrm{DL}$ is comparable to the previous results. ${ }^{19: 2 l}$ The relative standard deviation of the same modified electrode in five successive scans was about $3 \%$ for $100 \mu \mathrm{MH}_{2} \mathrm{O}_{2}$. confirming the significant reproducibility of the PTAPPNW + SWNT + Nafion/GCE for the determination of $\mathrm{H}_{2} \mathrm{O}_{2}$ in biological $\mathrm{pH}$.

The modified GCE prepared with SWNT, Nafion and polyporphyrin nanowire can easily be determined $\mathrm{H}_{2} \mathrm{O}_{2}$ by amperometric method at low overpotential such as $0.0 \mathrm{~V}$. and provides high sensitivity good DL and reproducibility. Therefore this modified electrode may be applied to the detection of $\mathrm{H}_{2} \mathrm{O}_{3}$ produced by enzyme cataly tic reaction in physiological systems.

\section{Conclusion}

Nanowires of polytetrakis (o-aminophenyl)porphỵrin (PTAPPNW) were fabricated by electrochemical polymerization with the cyclic voltammetric method in AAO membranes. PTAPPNW was easily prepared with a very uniform shape. The PTAPPNW + SWNT + Nafion/GCE exhibited strongly enhanced voltammetric and amperometric sensitivity towards $\mathrm{H}_{2} \mathrm{O}_{2}$ in a PBS solution at $\mathrm{pH} 7.4$. Based on the results of the amperometric method. the response time was very short. and the linear regression equation was obtained in the very low concentration region of less than $1.0 \mathrm{mM}$ at an applied potential of $0.0 \mathrm{~V}$. Therefore, the PTAPPNW + SWNT + Nafion $/ \mathrm{GCE}$ can be used to monitor $\mathrm{H}_{2} \mathrm{O}_{2}$ at very low concentrations in biological $\mathrm{pH}$ as an efficient electrochemical $\mathrm{H}_{2} \mathrm{O}_{2}$ sensor. This result was attributed to the synergic effect between porphyrinnanowire as an electroconducting polymer, SWNT as an effective electron transfer mediator. and Nafion as a negativelycharged binder.

Acknowledgments. This research was financially supported by the Ministry of Education Science Teclunology (MEST) and Korea Industrial Teclunology Foundation (KOTEF) tlurough the Human Resource Training Project for Regional Innovation.

\section{References}

1. Halliwell, B.; Gutteridge, J. M. C. Free Radicals in Biolog' and Medicine, Brd Ed; Clarendon Press: Oxford, 1999

2. Imlay, J. A.; Linu, S. J. Bacteriol. 1987, 169, 2967.

3. Hampton, M. B.; Orrenius, S. FEBS Lett. $1997,11+, 552$

4. Clement, M. V; Ponton, A.; Pervaiz, S. FEBS Lett. 1998, +40, 13.

5. Gonzalez-Flecha, B.; Demple, B. J. Bacteriol 1997, 179, 382.

6. Chance, B.; Sies, H.; Boveris, A. Physiol. Rev 1979, $59,527$.

7. Bai, T.; Rodriguez, A. M.; Melendez, T. A.; Cederbaum, A. I. J. Biol. Chent 1999, 274, 26217.

8. Matsumoto, A.: Okado, A.: Fujii, T.: Fujii, I.; Egashira, M.: Niikawa, N.: Taniguchi, N. FEBS Lett. 1999, $\$ 13,246$.

9. Takagi. Y.: Mitsli. A.: Nishiyama. A.: Nozaki, K.: Sono. H.: Gon, Y.: Hashimoto, N.; Yodol, I. Proc. Matl Acad Sci. US. 1999. 96.4131

10. Rhee, S. G. Science 2006, 312, 1882

11. Stone, J. R.: Yang, S. Antioxid. Redox Signal. 2006, 8, 243

12. Veal, E. A.; Day, A. M.; Morgan. B. A. 1/ol. Cell 2007, 26, 1

13. D'Autreaux, B.: Toledano, M. B. Not. Rev Mol. Cell Biol. 2007, 8,813 .

14. Giorgio, M.; Trinei, M:- Migliaccio, E; Pelicci, P. G. Nat. Rev. Hol. Cell Biol 2007, 8, 722 .

15. Poole, L. B.; Nelson, K. T. Cum. Opin. Chent. Biol. 2008, $12,18$.

16. Finkel, T: Serrano, M: Blasco, M. A Notthe 2007, $\$ 48,767$.

17. Barnham, K. T.; Masters, C. L.; Bush, A. I. Nat. Rev. Lrtg Discoverv 2004, 3, 205.

18. Lin, M. T.; Beal, M. F. Nature 2006, 413, 787.

19. Inamo, M.; Funahashi, S.; Tanaka, M. Inorg. Chem. 1983, 22. 3734 .

20. Besteman, K: Lee, I.-O.: Wiertz, F. G. M.: Heering, H. A.; Dekker, C. Nano Lett. 2003, 3, 727.

21. Qu, F.: Yang, M.: Tiang, J.; Feng, K.: Shen, G.; Yu, R. Electrochem Commun 2007, 9, 2596.

22. Boo, H.: Jeong, R.-A.; Park, S.; Kim, K. S.; An, K. H.; Lee, Y. H.; Han, T. H.; Kim, H. C.; Chung, T. D. Anal Chem 2006, 78, 617.

23. Valentini, F.; Amine, A.; Orlanducci, S.; Terranova, M. L.; Palleschi, G. Anat Chem 2003, 75, 5413 .

24. Wang, H.-S.; Li, T.-H., Jia, W.-L, Xu, H.-Y. Biosens. Bioelectron. $\mathbf{2 0 0 6}, 22,664$

25. Zhang, Y; Cai, Y.; Su, S. Anal Biochent 2006, $350,285$.

26. Hu, C; Chen, X; Hu, S. J. Electromal. Chem. 2006, $586,77$.

27. Wang, I.: Li, M.: Shi, Z.; Li, N.: Gu, Z. Electroanahssis 2002, 14, 225 .

28. Jeong. H.; Teon, S. Sensors 2008, 8,6924.

29. Wu, K, Fei, J.: Hu, S. Anal Biochem. 2003, 318, 100.

30. Wang. Z-H.: Liang, Q.-L.: Wang, Y.-M:Lno, G.-A. J. Electroanal. Chem $2003,540,129$

31. Seol, H.: Jeong. H.; Jeon, S. J. Solid State Electrochem. Online First.

32. Zhu, L.; Zhai, J; Yang, R.; Tian, C.; Guo, L. Biosens. Bioelectron. $2007,22,2768$. 
33. Zhang, M.; Gorski, W. J.Am. Chem. Soc. 2005, 127, 2058.

34. Zeng, I.; Gao, X.: Wei, W.; Zhai, X.: Yin, J: Wu, L.: Liu, X.: Liu, K.; Gong, S. Sens. Actuat. B: Chem. 2007, 120, 595.

35. Sha, Y.; Qian, L.; Ma, Y; Bai, H.; Yang, X. Talanta 2006, 70, 556.

36. Yu, X.: Chattopadlyyay, D.; Galeska, I.; Papadimitrakopoulos, F.; Rusling, J. F. Electrochem. Commun. 2003, 5, 408.

37. Wang, T; Musameh, M: Lin, Y. J. Am. Chent. Soc. 2003, 125, 2408 .

38. Toshi, P. P.: Merchant, S. A.; Wang, Y.: Schmidtke, D. W. Anal. Chem. 2005, 77, 3183.

39. Xu, Y : Pelursson, P. E.; Chen, L: Zhang, R:; Zhao W. J. Phes. Chen. $C$ 2007, 111,8638

40. Wang, Y.: Wei, W.: Zeng, J.: Lin, X, Zeng, X. Microchim. Acta $2008,160,253$.

41. Takamura, K.: Matsumoto, T. Anal. Bioanal Chem. 2008, 391, 951.

42. Kim, Y. D. Teon, S. Anal. Sci. 2001, 17, a97.

43. Martin, C. R. Science 1994, 266, 1961

44. Martin, C. R. Chem. Mater. 1996, 8, 1739

45. Parthasarathy, R. V.; Martin, C. R. Chem ifater. 1994, 6, 1627.

46. Pu, M.; Zhu, Y.; Tan, R: Shi, G. Adv. Mater, 2001, 13, 1874.

47. Zhi, L. J.: Gorelik, T.; Wu, J. S.; Kolb, U,; Mullen, K. J. Am.
Chem. Soc. 2005, 127, 12792 .

48. Piao, Y. Z.: Lim, H. C.: Chang, I. Y.; Lee, W. Y.; Kim, H. S. Electrochim. Acta 2005, 50, 2997.

49. Jin, K. W.; Yao, B. D.; Wang, N. Chem. Phys. Lett. 2005, 409, 172 .

50. Hou, S. F.; Harrell, C. C.: Trotün, L.: Kohli, P.: Martin, C. R. J. Am. Chem. Soc. 2004, 126, 5674 .

51. Chu, S. Z.; Inoue, S.; Wada, K:- Kurashima, K. J. Phys. Chemt. $B$ $2004,108,5582$

52. Yuan, T. H.; Wang, K.; Xia, X. H. Adv. Funct. Hater. 2005, 15, 803.

53. Chen, W. Xia, X. H. Chent Phys Chem 2007, 8, 1009.

54. Chen, W. Xia, X. H. Ads: Funct Hoter, 2007, 17, 2943.

55. Broncová, G.: Shishkanova, T. V.: Matẹjka, P.: Volf, R.: Kral, V. Anal Chim .1cta 2004, 511, 197.

56. Chen, C. X.: Gao, Y. H. Electrochim . Acta 2007, 52, 3143

57. Xian, Y. Z; Wang, H. T.; Zhou, Y. Y.; Pan, D. M.; Liu, F.; Jin, L. T. Electrochent Conmun 2004, 6,1270 .

58. Yang, C. M.: Yi, J. L.: Tang, X. I:; Zhou, G. Z:; Zeng. Y. React. Funct Poly 2006, 66, 1336 .

59. Liang, H. P; Guo, Y. G.; Hu, J. S.; Zhu, C. F ; Wan, L. T.; Bai, C. L. horg. Chent $2005,4,3013$.

60. Jeong, H.; Kim, H.: Jeon, S. Hicrochem. J. 2004, 78, 181. 